\title{
Imaginando la solidaridad
}

\section{Imagining solidarity}

\author{
Joan Baltà; Cristian López; Laila Medina; Pablo Passols; Liliana Vargas \\ Universitat Autònoma de Barcelona \\ joan.balta@campus.uab.es \\ Cristian.LopezR@campus.uab.es \\ LailaFatima.Aljende@campus.uab.es \\ PabloAlejandro.Passols@campus.uab.es \\ liliana.vargas@javeriana.edu.co
}

\section{Resumen}

El objetivo es básicamente intentar problematizar esta concepción de la solidaridad que se presenta como obvia, no pasible de crítica, políticamente correcta, masiva, positiva, transparente, buena, estética... Se podrían agregar otros tantos atributos, pero creemos que de momento bastan para caracterizar un tipo de solidaridad concreta y práctica, una tendencia en la sociedad actual, un tipo de intercambio simbólico que se establece sobre relaciones asimétricas y desiguales, $\mathrm{y}$, de algún modo reproductoras del sistema en el que tienen lugar.

Palabras clave: Solidaridad; Intercambio simbólico;

Relaciones asimétricas; Reproducción social

\begin{abstract}
Our aim is, basically, to try to trouble this notion of solidarity that is launched as obvious, noncriticisable, politically correct, massive, positive, transparent, good, aesthetic... We would be able to add other attributes, but they are enough to characterize a specific and useful kind of solidarity, a present society's tendency, a sort of symbolic exchange established over asymmetric and unequal relations and, also reproductive of the system where they take place.
\end{abstract}

Keywords: Solidarity, Symbolic exchange; Unequal relations; Social reproduction

\section{Introducción}

La sociedad europea del siglo XIX, desde los Urales hasta el atlántico portugués estuvo marcada por el cambio permanente: Revolución Industrial, sistema capitalista, sociedad de clases, gradual desmoronamiento del Antiguo Régimen, consolidación de la sociedad burguesa, etc. Las ideas de Modernidad y Progreso (entendido como científico, moral y tecnológico) hegemonizaron el panorama junto a los valores de la Revolución Francesa. 
La abolición de la esclavitud, las migraciones del campo a la ciudad, la crisis de la estructura de gremios, y la aparición de actividades económicas y procesos tecnológicos (por nombrar sólo algunos aspectos), fueron consolidando lo que comenzó a llamarse clase obrera: una clase que encontró sus teóricos, narradores y políticos en las nuevas fuerzas políticas del siglo XIX, esto es el socialismo, el comunismo, el sindicalismo, y el anarquismo, todos en sus múltiples variantes. A mediados del siglo XIX esta clase obrera creó sus primeras organizaciones: el sindicato, en el marco del Estado Nación; y las sucesivas Internacionales ${ }^{1}$ como perspectiva de una lucha que excedía los límites nacionales.

En este contexto, el término "solidaridad" emerge como nuevo valor moral que traduce aspectos de la caridad cristiana, pero modificándolos en sus alcances y acciones prácticas. Derivado del campo jurídico, el término solidaridad apuntaba a constituirse como medio de ayuda y colaboración entre los desfavorecidos con vistas a la lucha política, especialmente obrera-sindical. Ya el anarquismo había introducido la idea solidaridad, entendiendo el apoyo mutuo como uno de sus pilares fundamentales. Así, la solidaridad aparece como valor secular diferenciándose de la caridad como valor religioso.

El presente artículo consta de cinco partes en las que se desarrollan distintos aspectos de la solidaridad en el contexto de la sociedad actual. Intentamos pensar el lugar de la solidaridad, sus prácticas, definiciones, e inserción en el imaginario de una sociedad en cambio (posmoderna, tardo moderna en crisis, modernidad líquida, etc.). Hay una diversidad de prácticas solidarias y modos de conceptualizarla, pero decidimos concentrarnos en aquellas más específicamente mediáticas, aquellas que no sólo crean discurso sino también una imaginería asociada para el público masivo de una sociedad que consume cada vez más valores. Esta solidaridad produce imágenes que se multiplican al infinito: sujetos solidarios, objetos de solidaridad, fines de la solidaridad, símbolos, consignas, lugares, imagen corporativa de las organizaciones, etc.

El objetivo es aportar elementos para problematizar una concepto de solidaridad aparentemente obvio, no pasible de crítica, políticamente correcto, masivo, positivo, transparente, bueno, estético. Podríamos agregar otros tantos atributos, pero creemos que de momento bastan para caracterizar una solidaridad concreta y práctica, un tipo de intercambio simbólico establecido sobre relaciones asimétricas y desiguales, y, de algún modo reproductoras del sistema en el que tienen lugar.

En la primera parte se trazan una historia y posibles definiciones del concepto de solidaridad, a la vez que un recorrido sumario por algunas de las características de la solidaridad en el contexto los imaginarios actuales. En la segunda parte se aborda la perspectiva de Castoriadis sobre imaginario social a modo de base teórica sobre la que discutimos y trabajamos. Luego, en la tercera parte se ofrece una mirada de la solidaridad desde el punto de vista del debate Moderno/Posmoderno. En la cuarta parte se aborda la construcción del Otro en las prácticas e imágenes de la solidaridad: la alteridad así construida pide ser problematizada en tanto implica un nosotros y un ellos que deben ser urgentemente criticados. Finalmente, las últimas dos partes apuntan elementos para pensar el fenómeno de la solidaridad en una sociedad donde el consumo se constituye en práctica central: constitutiva de sujetos, identidades, y valores sociales. En este sentido la solidaridad cotiza en el mercado de las emociones, ese mundo simbólico que se construye en la interacción social poniendo en relación subjetividades en el marco de un imaginario social dominante.

1 Por ejemplo la Primera Internacional entre 1864-1876, y la Segunda Internacional entre 1889-1916. 


\section{Límites de lo Imaginario}

La solidaridad no es un imaginario sino que es un concepto o valor que atraviesa varios imaginarios. A lo largo de este capítulo se tratará de ver cómo ha surgido y evolucionado la idea de solidaridad en el contexto de la Modernidad y el capitalismo del siglo XIX, y sus metamorfosis, cambios, y nuevas prácticas en la trama de la sociedad actual que caracterizaremos como Posmodernidad, sociedad posmoderna, tardo moderna o de la modernidad líquida (según los autores de que se trate).

Si bien no es un imaginario, la solidaridad como valor moral y práctica social ha contribuido a la producción de imágenes y por lo tanto aporta a los imaginarios que atraviesa elementos particulares. Si bien más abstracta y menos mediatizada, concreta y simbólica, política y humanista, la solidaridad de la modernidad no era independiente de la lucha política y sindical, por lo que sus símbolos están ligados a otros valores como Fraternidad, Unión, etc. La sociedad actual, en sus prácticas especializadas y a partir de unas posibilidades técnicas inéditas hace dos siglos, ha contribuido a la proliferación de imágenes sobre la solidaridad. Aparece así una producción de imágenes y ampliación de las prácticas que exceden los contenidos originarios del concepto.

El imaginario entendido como "un conjunto de producciones, mentales o materializadas en obras, sobre la base de imágenes visuales (cuadro, dibujo, fotografía) y del lenguaje (metáfora, símbolo, relato), que formando conjuntos coherentes y dinámicos poseen una función simbólica en el sentido de una acoplamiento de sentidos propios y figurados". La solidaridad podría entenderse dentro del relato de la modernidad como concreción del legado de la fraternidad, ya que con el tiempo son términos se fueron usando como sinónimos. A su vez, las prácticas y el concepto mismo han evolucionado desde el uso jurídico al uso político, y desde las prácticas sociales hacia experiencias individuales.

Hoy día se puede observar una producción de imágenes de la solidaridad cuyo principal objetivo parece ser la sensibilización, la puesta en imagen tanto del sujeto como (especialmente) del objeto solidario, mostrar los resultados "concretos" de la solidaridad, y por qué no una visualizar los nuevos gestores que han desplazado al estado y al sindicato en la práctica solidaria: las ONG's como actores intermediarios que construyen su propia imagen corporativa para consolidar la credibilidad de su accionar transparente. La solidaridad está siempre inmersa en discursos a los que aporta un valor ético de responsabilidad, sensibilidad y preocupación social. Por eso, podría pensarse que no genera por sí misma un imaginario sino que matiza de un modo particular los discursos que atraviesa a partir de una producción discursiva e imaginal

\section{Solidaridad y Caridad en la Modernidad}

Ambos términos tienen derivas paralelas manteniendo la misma distancia y cercanía que separa la religión de lo político. En la Modernidad ambos términos apuntaban a la ayuda mutua y al apoyo de un "otro" necesitado; pero ese "otro" estaba más bien ligado por características de semejanza: misma religión, igual condición, problemas similares, posición de clase. Sin embargo, las prácticas y las conceptualizaciones difieren, pues los objetivos y la historia de ambos conceptos son diferentes.

Rastreando en las lenguas de origen latino tenemos que tanto solidaridad como caridad tienen las mismas raíces greco-latinas y presentan una similitud muy grande: solidarité, solidarietà, 
solidariedade, solidaritat; charité, carità, caridade, caritat. Incluso en alemán se usa el vocablo solidarität.

En el diccionario de la Real Academia Española encontramos que el término "solidaridad" aparece por primera vez en la edición del año 1869: esto podría indicar que entre la edición anterior de 1852 y la del año de su aparición el término estaba ya en uso, o sea que a mediados del siglo XIX tenemos un término nuevo en el castellano que se define como "Responsabilidad in solidum". La palabra deriva de "solidario", un término jurídico cuya definición reza: "adj. Se aplica a las obligaciones contraídas in solidum y a las personas que las contraen". Este es el debut del término solidaridad que define jurídicamente la responsabilidad del derecho romano entendida como "todos para uno y uno para todos"; la indicación in solidum (en total, por entero, por el todo) expresaba así la facultad u obligación común a dos o más personas que puede ejercerse o cumplirse por cada una de ellas.

A su vez, tenemos la vertiente moral del término ligada a "sólido", que en un sentido metafórico, ya desde el siglo XVIII se definía como cualidad de "firme y establecido con razones fundamentales y verdaderas" (RAE, 1739).

Hacia $1914^{2}$ la RAE agrega en un suplemento una nueva acepción de los términos solidaridad y solidario. La primera aparece como "Adhesión circunstancial a la causa o a la empresa de otros"; por lo tanto solidario es aquel "sujeto ligado por solidaridad". En la siguiente edición queda bien clara la relación entre la familia de términos y sus etimologías: sólido, del latín sólidus; solidario, de sólido; solidaridad, de solidario.

En la década de 1920 la familia de términos se completa por un lado con la definición de solidario como "Adherido o asociado a la causa, empresa u opinión de otro" (1925). Y luego, en la edición de 1927, se amplía la familia con la aparición del término "solidarizarse", es decir el verbo en su modalidad reflexiva: "hacerse/volverse solidario". Pero, es interesante remarcar que el verbo solidarizarse o solidarizar está ligado fundamentalmente la acepción nueva de solidario, no a la jurídica.

Finalmente el último cuarto del siglo XX nos aporta dos novedades que van en consonancia con una época de profundas mutaciones y cambios políticos, sociales y culturales. El diccionario de la RAE de 1984 incluye en la definición de Solidaridad una acepción sociológica: "En sociología, característica de la sociabilidad que inclina al hombre a sentirse unido a sus semejantes y a la cooperación con ellos" (RAE, 1984). Y su correspondiente nueva acepción de "solidario" como "ligado a otro por una comunidad de intereses y responsabilidades." (RAE, 1984)

En 1992, la edición del diccionario nos muestra que el sentido jurídico de solidario queda ahora en segundo lugar para dejar el primero a la acepción conocida y usual (adherido a causa, empresa u opinión de otro). Lo mismo sucede, entonces, con la definición de solidaridad cuya primera acepción pasa a ser la de adhesión circunstancial a una causa, y no ya la definición jurídica. En ambos casos desaparece la definición sociológica.

En cuanto al concepto de caridad es más antiguo y se define como la tercera y la más importante de las virtudes teologales ${ }^{3}$ : amar a Dios por sobre todas las cosas y al prójimo como a nosotros mismos. El término tiene su origen en el latín caritas y el griego charitas (gracias), y su uso comenzó por lo

\footnotetext{
2 En esos años, coincidentemente, los trabajos de Durkheim definían los lazos de solidaridad mecánica y orgánica.
}

3 En el cristianismo las virtudes teologales son: fe, esperanza y caridad (cuyo objeto es Dios). 
menos en el siglo X (en francés, charité). En castellano la RAE amplía el término más allá de la práctica de limosna que se presta a los necesitados, incorporando también la acepción de "procurar refresco de vino, pan y queso o cosa parecida, que en algunos lugares se da por las cofradías a los que asisten a la fiesta del santo que se celebra". También se incluye como caridad la costumbre de muchos pueblos pequeños de agasajar con motivo de la honra de un difunto.

\section{Dimensiones y aspectos}

Tanto en caridad como en solidaridad podemos analizar dos dimensiones, esto es una moral y otra práctica. En la caridad, la dimensión moral es una virtud, opuesta a la envidia y la animadversión, que propugna la unión con el otro, el prójimo, a través de Dios. Se trata siempre de una preocupación por el semejante a través y con la mediación de Dios. La práctica concreta incluye una dimensión material que son la limosna o los alimentos, así como una organización social que especialmente en el siglo XIX oponía ricos caritativos a pobres desfavorecidos.

La solidaridad, en su dimensión moral se define en el apoyo de una causa, adherir a una empresa sin ninguna referencia al ámbito religioso. Hay una ligazón con lo político ya que aparece en el contexto de las luchas obreras de mediados del siglo XIX con prácticas concretas de apoyo mutuo para la realización de huelgas y medidas de fuerza. En el caso de la huelga general, por ejemplo, la solidaridad jugaba un papel fundamental en lo material ya que permitía desarrollar acciones de ayuda para conseguir fondos y alimentos mientras durase el conflicto. Aquí los fondos de huelga eran la práctica más usual. Pero no se debería olvidar la importancia de la dimensión simbólica ya que los comunicados de apoyo, las declaraciones, los saludos o los repudios podían ser muestras o expresiones de solidaridad.

En el caso de la caridad se puede hablar de un sujeto individual que desarrolla una virtud hacia un objeto también individual considerado como semejante, prójimo, próximo. Inversamente la solidaridad tiene en el ideario de la Modernidad un sujeto colectivo que, en principio, se solidariza o confraterniza con otro/s sujetos colectivos: la relación se da entre colectivos o dentro de un mismo colectivo.

Entre Caridad y Solidaridad aparece uno de los pilares de la Revolución Francesa: el concepto de Fraternidad suele ser usado frecuentemente como sinónimo de ambos. Pero quizás deba entenderse más que como sinónimo como la expresión de los límites mismos de las prácticas caritativas o solidarias, o sea el Estado Nación que adquiere su fisonomía moderna en el siglo XIX. Fraternidad, consigna más ambigua que libertad o igualdad, terminó quedando dentro de los límites de los Estados en la imposibilidad de establecer estrategias que pudiesen llevar los cambios radicales más allá de Francia. Por ende, y también debido a las dificultades de comunicación espacial, tanto la caridad como la solidaridad quedaron por casi doscientos años confinadas a los límites de los Estados Nación.

Ya en el siglo XX la solidaridad se consolida como valor y práctica política, sobre todo sindical. Tiene concretas dimensiones materiales y económicas, convirtiéndose en uno de los pilares de la organización obrera. A la vez la dimensión simbólica, que como se dijo más arriba consistía (y aún hoy sigue consistiendo) en declaraciones, saludos, comunicados, repudios. Se trata de ayudar a iguales de clase, es decir que se sigue pensando en un "otro" que en el fondo es "alguien como nosotros", "uno de nosotros", ante una situación en la que "nosotros mismos" podríamos estar: desocupados, pidiendo aumentos de salarios, resistiendo despidos, etc. 


\section{Apuntes sobres Solidaridad y Posmodernidad}

Si bien las metamorfosis de la Solidaridad en la sociedad posmoderna se tratarán más adelante (cap. $3,4,5$ ), vale la pena dejar esbozados tres aspectos que consideramos fundamentales: la proliferación de imágenes sobre el tema, esto es una imaginería de la solidaridad; las acciones y prácticas denominadas solidarias de la sociedad civil se dan en y a través de instituciones independientes de partidos políticos y sindicatos; la construcción del objeto de la solidaridad no ya como semejante, igual o "alguien como nosotros" sino como "otro", diferente, multi y lejano, ubicado en otro mundo.

\section{a. Solidaridad en imágenes}

El imaginario actual de la solidaridad está íntimamente ligado en la práctica a las ONG's, que en muchos casos son herederas de las luchas y posiciones ideológicas de los años '70, pero en otros tantos caso son organizaciones nuevas y con un ideario y prácticas diferentes. Más allá de las diferencias, se trata de una nueva sensibilidad hacia los problemas sociales y la asunción de una responsabilidad en su solución. Sin embargo, el camino parece ser la relación individual, subjetiva, hipermediatizada, con un otro que ya no es cercano, ni igual, ni semejante. La materialización es en general dinero a ser administrado por la Organización receptora y ejecutora de la solidaridad. Pero hay que apuntar también que las acciones de voluntariado y de trabajo social han tenido un gran crecimiento ampliando la esfera de involucramiento del sujeto solidario.

Las imágenes más frecuentes trabajan metafóricamente sobre las manos como "unión", y la mirada como reflejo/espejo de la humanidad. Pero son de una complejidad de análisis que excede largamente una clasificación fácil. En general los niños tienen un protagonismo indiscutible, a veces en grupo, pero generalmente solos, mirando a la cámara e interpelando con una sonrisa, con expresión triste o con ojos anhelantes. También hay una búsqueda evidente de describir y mostrar en su mejor aspecto a las personas objeto de la acción solidaria, evitando imágenes extremas de pobreza o enfermedad. En ese aspecto deben ser legibles, dentro de lo posible, datos como raza, continente, condiciones de vida, y sobre todo necesidad de ayuda.

\section{b. Solidaridad en acción}

Tal como se muestra en las imágenes y textos de algunas organizaciones solidarias habría 3 momentos de la solidaridad: la sensibilización y la percepción de una realidad o situación asimétrica; un momento de colaboración o acción solidaria; y un resultado o producto de la solidaridad. En cuanto a la sensibilización las imágenes intentan mostrar la situación problemática: desastres naturales, pobreza, desocupación. La colaboración o acción solidaria puede adquirir las formas del voluntariado o de la donación material (dinero) mediante tarjetas de crédito, depósitos bancarios, efectivo, alimentos, medicamentos, ropas. En el caso de las organizaciones políticas se siguen manteniendo los criterios tradicionales de las manifestaciones de apoyo o adhesión, por supuesto sin dejar de lado los aportes de dinero y la búsqueda de acción conjunta con vistas a objetivos políticos.

En las imágenes el resultado o producto de la acción solidaria es muchas veces simbólico o inmaterial: sonrisas, niños "felices", abrazos, manos, besos. Otras veces más bien material: buena alimentación, un trabajo dignificador de la humanidad, ayuda al desarrollo. Aunque no siempre aparece, la imagen del sujeto solidario muestra la inmaterialidad de la satisfacción por los resultados logrados: ser solidario, tener ideales, ser responsable, trabajar en equipo. 


\section{c. Solidaridad en consignas}

Si en otro momento las consignas solidarias iban dirigidas al apoyo o adhesión a una causa ajena y a la vez propia en tanto "otro como yo", hoy tienen objetivos más generales, formulaciones más abstractas y particularmente llama la atención su orientación por momentos utópica. Por ejemplo:

- Llamado mundial a la acción contra la pobreza

- Derechos Humanos de los niños

- La educación como fuerza de cambio

- La universalidad de la humanidad

- Solidaridad hacia colectivos extremadamente numerosos y lejanos territorialmente

\section{Solidaridad y crítica}

Como se ha dicho antes abordamos la Solidaridad a la vez como producción discursiva y como producción de imágenes. Discursiva desde lo que se define como solidaridad, ese intercambio finalmente simbólico que en tanto juego de la desigualdad pone en relación un sujeto de la solidaridad y un "otro" objeto de la misma, que forman parte de un sistema que genera la desigualdad misma. La solidaridad no sería más que un medio simbólico y material, no sería más que un intento de la ilusión de corregir las desigualdades propias del sistema del que ambas partes participan. Entendida de este modo la solidaridad se convierte en un espectáculo en el que los actores solidarios y los objetos de la solidaridad juegan sus papeles cada uno en ausencia del otro, mediatizados por la organización solidaria. Pero el peso parece estar puesto en la construcción y la imaginación del otro, en la evaluación las causas del problema y en una respuesta no pensada desde el "otro" sino siempre en las coordenadas culturales del que realiza la acción solidaria.

Podríamos preguntarnos si finalmente en la pasión "desinteresada" de la solidaridad se construye ese "otro" como diferente, o si en realidad la alteridad no termina siendo la proyección en un espejo vacío de la propia imagen de un sujeto que ya no ve; alteridad construida por un sujeto solidario que en su monólogo ya no escucha sino su propia voz, sus propias necesidades, su propia "conciencia", sus propios intereses. Quizá en esa oscilación entre ceguera, sordera y voluntad, es decir dentro de esos límites, deban entenderse hoy la acción y las posibles definiciones de la Solidaridad.

\section{Cornelius Castoriadis y lo imaginario}

La vieja Grecia supo sintetizar, he ahí uno de sus grandes méritos, el pensamiento mítico y el pensamiento racional. El mito, que había inundado de poesía la geografía cultural griega a partir de las concepciones antropomórficas de los poetas Homero y Hesíodo, comienza a perturbar la mente de los griegos pensantes.

Parménides, tras desestimar el conocimiento adquirido por los sentidos y guiado por las evidencias de la razón escribirá un poema épico, de carácter alegórico, que relata la elección del camino -el único camino, según él- que lleva hacia la Verdad, y que a la postre, sentará las bases del pensamiento de Occidente. 
En Sobre la naturaleza, dice Parménides ${ }^{4}$ :

[Le habla la diosa]

Voy a decírtelo ahora mismo, pero presta atención a mis palabras, las únicas que se ofrecen al pensamiento de entre los caminos que reviste la búsqueda. Aquella que afirma que es Ser es y el NoSer no es, significa la vía de la persuasión -puesto que acompaña a la Verdad-, y la que dice que el No-Ser existe y que su existencia es necesaria, ésta, no tengo reparo en anunciártelo, resulta un camino totalmente negado para el conocimiento. Porque no podrías jamás llegar a conocer el No-Ser -cosa imposible- y ni siquiera expresarlo en palabras. [...] porque el pensar y el ser son una y la misma cosa. (Jaeger, Wemer, 1998)

Parménides afirma: o hay algo, o bien no hay nada. Es decir, "el No-Ser no existe" porque no podría siquiera ser expresado en palabras, no se puede conocer. Por tanto, sostiene: ser y pensar son lo mismo, porque el ser es lo pensable y aquello que puede ser pensado comprende al ser.

Por tanto, decir que el No-Ser existe es como decir que el No-Ser es, lo que es absurdo y claramente contradictorio, por lo que se debe rechazar.

En conclusión, afirma que "hay algo". Algo es, y este "algo es" es el ente. Ente significa "lo que tiene que ser" (una silla, la montaña, la raíz cuadrada, Odiseo), por lo que entonces el ente es necesario, necesario que sea, si no, no sería ente.

Hay que decir y pensar que el Ser existe, ya que es a Él a quien corresponde la existencia, en tanto es negada a lo que no es.

Este camino conduce al ser de Parménides al ser racional. Llevado por su estricto razonamiento -y por la necesidad de que el ser sea-, describe las características del ser: único, indivisible, inmutable, inmóvil, inengendrado, imperecedero e intemporal.

Por tanto, si no hay cambio, mutación, generación ni muerte -si no hay transcurrir ni devenir-, no tiene sentido hablar de tiempo. El ente parménico es un puro presente de duración continua, pero no durante el tiempo. No es que el ente permanezca igual mientras transcurre el tiempo: no, simplemente no hay tiempo.

No hay pasado ni futuro y no tiene sentido pensarlo, pues es pensar algo que ya no es (pasado) y algo que vendrá a ser después (futuro). Pensar en esos términos sería aceptar el absurdo y la contradicción: si el Ser es, entonces es y punto. No puede ser mañana o dentro de un tiempo. Y si el No-Ser no es, entonces no es. No puede, de pronto, ser algo.

A esto Castoriadis lo denomina: el ser como determinación. El Ser es determinado por Parménides; determinado a ser y no poder no-ser. El ser como determinación es la base de la ontología del pensamiento occidental.

Los principios ontológicos postulados por Aristóteles, por tanto, son válidos para todos los entes, pues se ocupan de todas las cosas que son. Éstos son:

a) Principio de identidad: "Todo ente es idéntico a sí mismo."

4 Aunque Castoriadis no retrocede tanto en el tiempo, creemos oportuno volver a Parménides para comprender el origen de todo. 
b) Principio de no-contradicción: "Ningún ente puede ser al mismo tiempo P y no-P".

c) Principio del tercero excluido: "Todo ente tiene que ser necesariamente P o no-P".

d) Principio de razón suficiente: "Todo tiene su razón o fundamento".

Estos fundamentos del pensamiento son los que Castoriadis llama indistintamente: la "ontología heredada", "lógica conjuntista-identitaria" o "lógica ensídica". Los grandes pensadores griegos (los antiguos) comparten un principio que imposibilita pensar la creación: de la nada nada sale. El ser, por tanto, responde a la determinación de la razón, pero como una creación de ella.

\section{Lo imaginario}

Cerca de cualquier punto del lenguaje hay un elemento que pertenece a la dimensión conjuntistaidentitaria, y, también, un elemento que pertenece a la dimensión de lo imaginario. Aun el más loco poema surrealista contiene una indefinida cantidad de lógica, pero a través de ésta el poema hace tangible lo Otro de la lógica. En Bach, la aritmética y las matemáticas están en todas partes; pero no porque tenga aritmética y matemáticas un clavicordio bien afinado es lo que es (Castoriadis, 1986).

Mundo y lenguaje se constituyen mutuamente, y el punto en común entre mundo y lenguaje reside en las significaciones imaginarias sociales. Del mismo modo que el lenguaje lleva a postular la existencia de las cosas como reales -pues al nombrarlas se las cosifica-, se toma un fragmento de lo real y se hace de él "algo" distinto y definido, que es, además, elemento de un conjunto también distinto y definido.

El mundo es lo que es en una instancia histórico-social. Pero también puede ser otra cosa; es fundamentalmente transformable, mutable, metamorfosearse. $Y$ ha sido efectivamente transformado, mutado y metamorfoseado. Ahora bien, siempre se encontró como artífice de este cambio a mutación a Otro (con mayúscula), o a otros (antepasados), o a nadie (azar). Los hombres nunca se sintieron capaces de asumir la creación de sí mismos, y proyectaron esta acción hacia fuera y hacia el pasado.

Castoriadis postula por tanto que es tiempo de superar esta "dependencia" que rige la construcción de las sociedades y de reconocer el papel que cada uno lleva adelante en tanto individuo social, representante y agente de la sociedad histórica. Lo histórico-social requiere para decidir sobre su destino que cada uno asuma una función autónoma de las acciones y las ideas. Los individuos parece decir Castoriadis- deben comprender que el mundo no se acaba en lo que ya es, que el mundo puede ser de otra manera.

\section{La creación no tiene explicación}

En el Timeo, Platón describe el caos primigenio y al Demiurgo organizador e impulsor del orden. Como de la nada nada sale, el Demiurgo no crea de la nada sino que pone un orden donde no lo había. Castoriadis coincide en que el hombre no puede crear ni un gramo de materia; él diría que "la materia esta ahí". Las cosas y el mundo tal y como se lo conoce se presenta, así, organizado y organizable.

Pero el hombre crea formas, ideas, que -finalmente- hacen a la esencia de las cosas. Pero hay entidades que no tienen correlato en el mundo sensible, pues pertenecen al mundo de la imaginación; 
por ejemplo: los dioses, las hadas, los monstruos, el inconsciente, las estructuras, los espíritus. La sociedad se hace cargo de las nuevas eidé a través de su aceptación y el reconocimiento del nuevo campo que están abriendo. Esta aceptación puede pasar por una etapa de discusión, pero, aun en ese proceso, se debate sobre un tema ya abierto, sobre una realidad ya posible.

La ontología heredada, al estipular la relación de causalidad como modelo de explicación, choca con la imposibilidad de encontrar una respuesta satisfactoria, racional, lógico-científica para lo imaginario. Castoriadis no se cansa de repetirlo: la creación es el paso del no-ser al ser, por tanto, la creación no tiene explicación.

\section{El elemento imaginario}

El imaginario social reúne una doble capacidad: el uso del signo (el ver lo que no es en lo que es), y de la finalidad (el ver lo que no es y podría ser).

Según Castoriadis, el mundo y la sociedad son posibles en tanto que postulación de conjuntos. Todo lo que se conoce a través de los sentidos es ejemplo de esto, pues la misma forma de conocer es agrupar en conjuntos: "Esto es $x$, pertenece a y." Todo lo que se llega a conocer es susceptible de ser colocado dentro de un conjunto.

Pero estos conjuntos pueden dejar de ser o comenzar a ser de manera diferente. Lo histórico-social no se agota en este modo conjuntizable del ser sino que hay un elemento que "airea" e indetermina toda relación: el elemento imaginario.

\section{El imaginario radical}

Con el imaginario radical Castoriadis reedita, en el plano ontológico, lo que Sigmund Freud hizo en el mundo psíquico: lo consciente, que es una cara del ser, es un rostro -finalmente-, una máscara; y el inconsciente, un sistema constituido por representaciones que han sido reprimidos y cuyo acceso al sistema preconsciente-consciente les ha sido denegado. Este inconsciente está habitado por una multiplicidad de fuerzas que se entrecruzan y que ocasionalmente acceden a lo consciente tomando prestada una forma.

La representación sólo puede formarse en y por la psíque, pues la psíque es, ella misma, emergencia de representaciones acompañadas de un afecto e insertas en un proceso intencional. Debe postularse necesariamente que la psíque es capacidad para hacer surgir una "primera" representación, una puesta en imagen (Castoriadis, 1989).

Pero: ¿de donde toma la psique los elementos de la representación?

Es completamente imposible comprender la problemática de la representación si se busca el origen de la representación fuera de la representación misma. La psíque, sin duda, es "receptividad de las impresiones", capacidad de ser afectado por; pero también es emergencia de la representación en tanto que modo de ser irreductible y único y organización de algo en y por su figuración, su "puesta en imagen".

La pulsión, según Freud, se origina en lo somático, pero para actuar sobre lo psíquico es necesario que ella "hable el idioma" de la psíque. Es decir, que encuentre su "traducción". Y esta traducción (o 
delegación) toma la forma de representación. Pero, dice Castoriadis "no hay un lazo predeterminado o una relación obligatoria entre la pulsión y su representante psíquico".

La psique es un elemento formativo que sólo existe en y por lo que forma y cómo lo forma; es formación e imaginación, es imaginación radical que hace surgir ya una "primera" representación a partir de una nada de representación, es decir, a partir de nada (Castoriadis, 1996).

Si lo llama imaginación radical es porque la creación de representaciones, afectos, deseos, por la imaginación humana es condicionada pero nunca predeterminada. La psíque humana se caracteriza por la autonomía de la imaginación, por una imaginación radical: no se trata simplemente e ver -o verse- en un espejo, sino la capacidad de formular lo que no está, de ver en cualquier cosa lo que no está allí (Castoriadis, 1996).

En el plano de la psíque, el imaginario radical se concreta en tanto que imaginación radical de los individuos, que tienen como fruto una multiplicidad de representaciones. En el plano histórico-social, el imaginario radical se concreta como imaginario social o instituyente. $Y$ de este imaginario emergen las significaciones.

El vínculo entre imaginación radical (en el plano de la psíque) e imaginario social (en lo histórico social) no es unilateral, de subordinación ni de utilidad. Cada uno rige en su campo confrontándose mutuamente, co-constituyendo al individuo social y a lo histórico-social.

\section{Las significaciones imaginarias sociales}

Las significaciones imaginarias sociales definen representaciones, deseos y actos de los sujeto de una manera absolutamente arbitraria. Las ideas de igualdad o de maternidad $u$ otras, son una creación del colectivo; carecen de sentido en sí mismas.

Las cosas sociales son sociales gracias a las significaciones que las constituyen y las hacen posibles. A su vez, las significaciones imaginarias sociales son posibles por las cosas instituidas por ellas que las encargan y figuran, transmiten y reproducen. Por lo tanto, la institución de la sociedad se corresponde con la materialización del magma de significaciones imaginarias sociales.

La unidad que se observa en el cuerpo social se debe a que se mantiene vivo su mundo de significaciones. Pero, aclara Castoriadis, las significaciones centrales no son significaciones de algo ni agregadas de algo, son ellas mismas las que dan existencia a ciertos objetos, y a cierto tipo de individuos y en definitiva a todo un mundo.

No se deben confundir las significaciones con lo que los individuos se representan -ya sea consciente o inconscientemente- o piensan. Las significaciones son aquellos por medio de las que y a partir de las que los individuos son formados como individuos sociales, con capacidad para participar en el hacer y representar social. Esto queda claro si se admite que ningún individuo representa el total de las significaciones, ni el total de la institución de la sociedad.

\section{La sociedad instituida/instituyente}

El imaginario social es instituido e instituyente. El individuo es instituido por ese imaginario y a la vez lo instituye. 
En esta permanente tensión entre las fuerzas de lo instituido y las fuerzas de lo instituyente, lo que define a una sociedad autónoma es su actividad de autoinstitución explícita y lúcida; es decir, el hecho de que ella misma se da su ley sabiendo que lo hace. Esta creación, apoyada en un imaginario radical con poder instituyente, se traduce en praxis: una acción que puede tomar apoyo en lo que es, para hacer existir lo que queremos ser (Carrizo, 1998).

El mundo común es, necesariamente, en cada momento institución de lo que es y no es, de lo que vale y no vale; así como de lo que es posible o lo que no lo es; tanto "fuera" de la sociedad como "dentro" de ella. Por esto mismo, también este mundo común es "presencia" de no ser, de lo falso, de lo ficticio, de lo simplemente posible, pero no efectivo. Este movimiento que surge a partir de lo posible/imposible constituye la "realidad" para una sociedad dada. Castoriadis afirma que la sociedad representa la fijeza/estabilidad relativa y transitoria de las formas/figuras instituidas en y por las cuales -y sólo en y por ellas- lo imaginario radical puede ser y darse existencia como histórico-social.

\section{La sociedad autónoma y la voluntad nietzscheana}

La autoalteración perpetua de la sociedad es su ser mismo, que se manifiesta por la posición de formas-figuras relativamente fijas y estables y por el estallido de estas formas-figuras que jamás pueden ser otra cosa que posición-creación de otras formas-figuras. Cada sociedad da existencia a su propio modo de autoalteración, a la que se puede llamar también su temporalidad, es decir, que se da existencia también como modo de ser (Castoriadis, 1989).

Castoriadis no acepta una vinculación entre esta idea de sociedad como "autoalteración perpetua", que él pregona, con el planteamiento nietzscheano de "la voluntad de poder". Sin embargo, la noción del mundo según Nietzsche ofrece, por su riqueza poética, elementos para pensar lo imaginario:

Aunque no puede inferirse una deuda directa, sería oportuno comparar el doble principio al que apelan ambos autores para la constitución de la realidad:

- lo apolíneo y lo dionisíaco en Nietzsche, y

- lo identitario y lo imaginario en Castoriadis.

\section{Apolíneo e identitario}

En la interpretación que hace Nietzsche de la tragedia griega define lo apolíneo como "La apariencia de plenitud de belleza del mundo del ensueño: las formas son elementos.

Sin embargo, el espíritu filosófico y artístico ve estas formas e intuye que detrás de su apariencia, como en el sueño mismo, hay algo más real y contundente que descifrar. Los griegos representaron bajo la figura de Apolo la apariencia plena de belleza del mundo interior de la imaginación. Es que Apolo es la medida, la armonía, la serenidad de aquel que se tiene a sí mismo en sus propios límites, sin desbordes ni desmesuras (Sanguinetti, 1999).

De esta manera, Apolo es representante del principio de individualización, lo que se corresponde con el principio de identidad con el que se construye la lógica conjuntista-identitaria. 


\section{Dionisíaco e imaginario}

Por otro lado, Nietzsche aporta el elemento dionisíaco:

El mundo estético dionisíaco es el de la embriaguez. Es la fuerza que arrastra en su ímpetu a todo el individuo hasta sumergirlo en un completo olvido de sí mismo como un huracán de vida ardiente. [...] Con la embriaguez dionisíaca caen las arbitrariedades de las barreras rígidas y hostiles que han levantado los hombres (Sanguinetti, 1999).

Lo dionisíaco lleva adelante la destrucción del principio de identidad, funde al individuo en el magma para que surja otra forma, otras eidé. Encontrar coincidencias mayores en estos autores haría necesaria una profundización de ambas obras. Aquí sólo se intenta sugerir una no tan sutil vinculación entre ambos pensadores. Donde sí puede aventurarse una coincidencia es en la intuición compartida de una ruptura en la cultura occidental. Esta fisura ha quedado reflejada en ideas que, si bien no similares, son en gran medida coincidentes: la represión de la vida (de la que habla Nietzsche) y la supresión de lo imaginario (concepto de Castoriadis).

\section{Pensar la modernidad y la posmodernidad como imaginarios}

Cornelius Castoriadis propone que el imaginario se enraíza en el orden del sentido, en el plano de unas finalidades rectoras que orientan toda la vida social de una cultura, las significaciones imaginarias comunes mantienen así, la integridad de lo social. Este imaginario sin embargo se juega en la pareja instituido - instituyente, el imaginario radical retomaría la posibilidad de transformación de lo simbólico, de lo instituyente frente al imaginario instituido (Ibáñez, 2003) con sus múltiples discursos.

Nos detendremos por ahora, en esta idea de Castoriadis, de que existe para lo moderno una serie de significaciones centrales. Pensaremos entonces en la modernidad y posteriormente en la posmodernidad, -acogiendo la propuesta de Jean Francios Lyotard, quien acuña el termino de lo posmoderno- más que como épocas como narrativas, que generan, sus propias imágenes, su propio imaginario podríamos pensar, para acoger la idea de Jean-Jacques Wunenburger y pensar el imaginario a partir de las imágenes que un determinado relato nos trae.

Iniciaremos este trayecto trayendo la imagen hegeliana de la historia, porque ella en buena medida define el ideal moderno de progreso y de historia, que todavía hoy podemos escuchar en algunos contextos, revisemos algunas citas que en la obra de Hegel nos permiten acercarnos a este imaginario. Todo lo que sucede en la historia sucede por la voluntad del hombre, porque el proceso histórico consiste en acciones humanas; y la voluntad del hombre no es sino el pensamiento del hombre expresándose exteriormente en acción. El progreso es el impulso ilimitado del espíritu del mundo, el objetivo de su ímpetu irresistible. La historia es el progreso de la conciencia de la libertad (Hegel, 1976).

Dentro de ellas, es clara la noción de progreso que atraviesa todo el imaginario moderno, progreso que se vera ligado posteriormente a un avance tecnoindustrial que dará a la modernidad uno de los rasgos que definirá su carácter.

Si aceptamos con Castoriadis que un conjunto de significaciones imaginarias comunes mantienen la integridad de lo social, y constituyen el cemento colectivo que liga a los individuos en torno a una 
única interpretación del mundo, la modernidad realizaría una entronación de la razón y mas concretamente de una forma de razón aquella que permitirá ver la racionalidad tecnoproductiva como central al proceso de desarrollo y de progreso. El relato Hegeliano de la Gran Historia permite pensar con claridad la dinámica que allí se despliega:

"Para que lo universal arribe a un acto tiene que concentrarse en lo uno de la actividad individual y poner a la cabeza una conciencia singular, pues la voluntad universal sólo es voluntad real en un sí mismo que es uno. Pero con ello, quedan excluidos de la totalidad de este acto todos los otros singulares y sólo tienen en ella una participación limitada. Por tanto, ninguna obra ni acto positivos pueden producir la libertad universal; a dicha libertad sólo le resta el obrar negativo, es solamente la furia del desaparecer".

Hegel que ejemplifica con claridad la imagen moderna de historia, proponen un gran sistema, que engloba dentro de sí tanto lo que le pertenece, como lo que se le opone, en esto consiste su juego dialéctico. Se trata de un ejercicio enfrentamiento positividad- negatividad, para producir unidad. Una búsqueda de coherencia a partir de una capacidad de racionalidad y de fraseo que puede ser entendida bajo la regla de incluir todas las frases bajo una identidad definida por frases precedentes, la identidad de la frase precedente es, en este caso, la noción de una universalidad que debe ser completada y que excluye en un ejercicio de negatividad a todo aquello que no sea posible universalizar.

La modernidad despliega entonces un juego de universales que busca articular dentro de una promesa de progreso, de emancipación, de avance de la humanidad. Es posible comprender la modernidad como un ejercicio de concatenación que elimina toda la potencia de las frases singulares bajo el principio de la inclusión obligada. La diferencia hace posible el juego, pues se trata precisamente de un ejercicio de inclusión de la diferencia, para la eliminación de la diferencia, como veremos más adelante.

Esta forma de narrar totalizante, es llamada por Lyotard metarrelato. El metarrelato carga necesariamente, en su intento de coherencia, un afán de totalización. Se construye una noción de subjetividad que no es divisible. "Sólo hay una historia para todo el mundo humano, sólo hay un sujeto para toda la historia" (Lyotard, 1996: 76). Occidente construye y representa una historia, tiene lugar así una narrativa que cobra sentido a partir de los presupuestos de su surgimiento, se construye con ella una humanidad, un sujeto, una nación, una conciencia que se narra, se crea la imagen de que avanzamos hacia un lugar que nos espera como meta deseada. Un acontecimiento sólo se introduce en la tradición, en la cultura, en la medida en que esté involucrado en la historia, esa historia y en ese imaginario de que esa historia se corresponde con la historia de la Humanidad.

La totalización por vía de estas nociones, lleva sin embargo aparejada la emergencia de un "Otro" de una resistencia, que Zigmunt Bauman entre otros autores, señala claramente en el problema judío, o en general en el problema de los restos del sistema (Bauman, 1993) (Lyotard, 1996). Ese Otro no aparece como externo al sistema, por el contrario, se encuentra y se ubica dentro de él, y Lyotard dirá que a causa de él: "parece como si se tuviera la necesidad de inventar la plaga de una contaminación interna". El acallamiento de esta plaga corresponde a una hegemonía y señala una resistencia, esa resistencia simplemente susurra "otro pasa antes que el uno" (Lyotard, 1996: 79). 


\section{Lo posmoderno ¿un giro en el imaginario moderno?}

Pensaremos ahora, modernidad y posmodernidad como dos bailarines en una pareja de baile, no es posible imaginar el uno sin el otro. La posmodernidad sería así, una inflexión de lo moderno que recoge aquello que se ha dejado de lado, que ha sido acallado en el intento de totalización del que hablábamos al principio, la modernidad liquida que Bauman propone, para hablar de aquello que otros denominan lo posmoderno, no es mas que una modernidad que se hace porosa, que deja pasar lo que el sistema moderno ha pretendido olvidar. Desde otros autores encontramos entonces, la imagen del juego de lo moderno y lo posmoderno, como pareja en movimiento.

La imagen del Ángelus Novus que Walter Benjamín recoge en el fragmento 9 de las Tesis de la Filosofía de la Historia, resulta particularmente interesante para esta discusión, por tratarse de eso precisamente, de una imagen, que propondremos, recoge claramente el imaginario moderno y al mismo tiempo el imaginario posmoderno, en su juego de duelo frente a lo moderno. Walter Benjamín trabaja su texto a partir de una imagen, una pintura de Klee que traeremos a continuación:

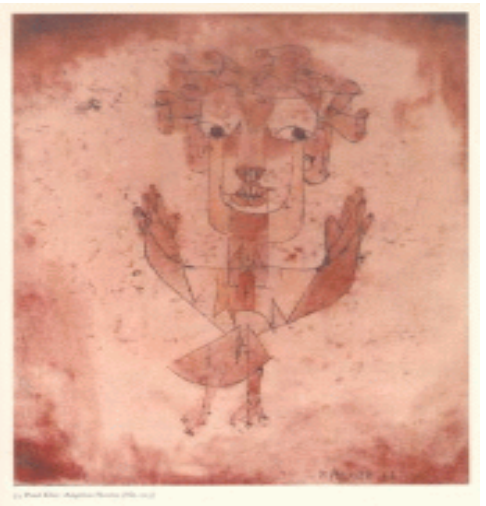

"Hay un cuadro de Klee que se llama Ángelus Novus. En él se presenta a un ángel que parece como si estuviese a punto de alejarse de algo que lo tiene pasmado. Sus ojos desmesuradamente abiertos, la boca abierta y extendidas las alas. Y ese deberá ser el aspecto del ángel de la historia. Ha vuelto el rostro hacia el pasado. Donde a nosotros se nos manifiesta una cadena de datos, él ve una catástrofe única que amontona incansablemente ruina sobre ruina, arrojándolas a sus pies. Bien quisiera él detenerse, despertar a los muertos y recomponer lo despedazado. Pero desde el paraíso sopla un huracán que se ha enredado en sus alas y que es tan fuerte que el ángel ya no puede cerrarlas. Este huracán le empuja irreteniblemente hacia el futuro, al cual él vuelve la espalda, mientras que los montones de ruinas crecen ante él hasta el cielo. Este huracán es lo que nosotros llamamos progreso". (Walter Benjamin).

Vemos entonces una clara la oposición entre Hegel y Benjamin, cada uno de ellos significa el compromiso con maneras opuestas de narrar la historia y por esto, con imaginarios radicalmente diferentes, cada uno se refiere a lo moderno pero de diferentes maneras, lo que en Hegel es una promesa de progreso, en Benjamín se convierte en desencantamiento. Lo posmoderno implica la ruptura de las promesas del imaginario moderno, lo sólido se hace liquido, lo seguro se convierte en peligro, el progreso comienza a mostrar sus rasgos de barbarie.

Frente a las múltiples interpretaciones que aun hoy se siguen haciendo al fragmento del Ángelus Novus, enfatizaremos en aquella que nos muestra con claridad la ruptura del gran relato -del metarrelato- de la historia que se da en ella...donde otros ven una cadena de datos, el ángel ve una catástrofe única que amontona ruina sobre ruina... su vuelo sin embargo, no puede detenerse pues el viento del progreso lo empuja hacia el futuro. La imagen nos trae también la de la fluidez irremediable, la velocidad con la que el viento empuja al ángel quien a pesar de haber vuelto la mirada, no puede detenerse.

La imagen del ángel de la historia, es para muchos la imagen del juego moderno- posmoderno y la denuncia de aquello que el gran relato del progreso deja de lado, podemos ver en el gesto del ángel que vuelve su cabeza hacia atrás para cambiar la mirada, (el quisiera despertar a los muertos, 
recomponer lo despedazado...) el ejercicio de la critica y del imaginario radical en tanto emancipación frente a un relato-imaginario instituido.

Diremos así que lo posmoderno, nos muestra aquello que los grandes relatos de la modernidad han ocultado, vemos las ruinas del progreso, aquellas sobre las que no hay que detenerse si se quiere continuar la marcha. Lo posmoderno se juega en esta imagen de algo que sale de control y contradice al gran relato. La noción de acontecimiento se juega precisamente en este hecho, aquello inesperado que rompe la cadena de significado del relato, que no puede ser subsumido, que escapa al discurso podríamos pensar.

Para introducir el tema central de este traba: el de la solidaridad en el mundo contemporáneo, como discurso dentro de un imaginario particular de occidente, rescataremos solamente un fragmento más de esta imagen, es precisamente el gesto del ángel que vuelve la mirada, a pesar del viento del progreso que en su velocidad hace dejar de lado las ruinas y la muerte que crecen sin control. Se trata precisamente de lo Otro del sistema, aquello que debe ser acallado.

Podemos pensar que los restos que los grandes relatos de la modernidad dejan en su camino, son tan constituyentes de ella como lo son sus productos mas preciados, son el lado oscuro de lo moderno, el reconocimiento de ellos, es lo que llamamos posmoderno, por eso no es posible pensar lo posmoderno sólo como una época.

La modernidad crece así, cargada de estrategias que buscan hacer algo con los restos, con los márgenes del sistema, se trata de medicalizar la locura, de civilizar a los incivilizados o de salvar y desarrollar a los pobres. Desde los relatos modernos se ha dado diferentes nombres a aquello que es alteridad, diferencia, resto de lo moderno. Los relatos de la solidaridad que operan desde este imaginario le dan también diferentes nombres a aquel con el que hay que ser solidario - a eso dedicaremos la siguiente parte de nuestro trabajo- por ahora solo diremos que muchos de los relatos de la solidaridad continúan operando dentro de estas nociones de desarrollo y de progreso. La noción y la promesa de progreso y de desarrollo sigue operando en ellos, el sistema en si mismo no cuestiona su marcha, es posible hacer compras y hacer caridad en la misma pagina de Internet, sin perder mucho tiempo eso si, todos estamos arrastrados como el ángel de la imagen Benjaminiana por el rápido viento del progreso, hoy en la promesa del neoliberalismo.

Sin embargo al leer hoy la imagen de Benjamín, tal vez ya no sabríamos, si el ángel esta horrorizado o se halla simplemente -como en el mundo contemporáneo- ávido de acontecimiento, solo para domesticar el acontecimiento, y restarle toda su fuerza de ruptura. El mira como miramos hoy en Internet el hambre en el mundo... tal vez haga un clic para donar desde su ordenador un dinero para algún niño en África o América Latina, después de eso tal vez compre en la misma pagina una camiseta para vestir en una fiesta que celebre la solidaridad en el mundo, la vida continua, el acontecimiento de la muerte ha perdido toda su fuerza. La pregunta por la posibilidad de un imaginario radical se hace más apremiante que nunca.

\section{El Otro de la solidaridad}

Quien es el otro de la solidaridad. ¿Lo es por sus propias características o bien por las preferencias del donante? 
Un simple vistazo a las imágenes de la publicidad de organizaciones destinadas a actividades solidarias, deja bien claro el otro de la solidaridad. Son niños y niñas del África negra o de comunidades indígenas de América Latina. Imágenes que parecen perfectamente escogidas para conmover. El perfil parece bien definido, en plena consonancia con el imaginario instituido. Solo con fenómenos como el tsunami de diciembre de 2004, se pasa a imágenes de destrucción ${ }^{5}$. Ahora bien, la diferencia parece clara. En el primer caso la ayuda es para los niños, en el segundo para la reconstrucción. Todo parece indicar que el otro de la solidaridad pretende conmover alta pero efímeramente, lo suficiente para tentar una acción teledirigida antes del impacto del próximo anuncio.

Pero esto solo son tentativas interpretativas de un fenómeno intuitivamente más complejo como es la alteridad. El otro. El necesitado que no tiene medios para dejar de serlo. El que se queda en su país. El que emigra a otros países. El que nos encontramos en las calles o en el metro. El que vemos por televisión. Filantropía. Racismo. El otro abrazado y repelido. Sociedades bajo el paradigma del individualismo que ensalzan la solidaridad. Sociedades fascinadas e impactadas por la desgracia ajena. Sociedades indiferentes pero cada vez más preocupadas por el otro. Cualquier terreno que permita la construcción de múltiples paradojas requiere de la problematización de sus términos. En este punto se presenta un recorrido por el estado simbólico de la alteridad en relación a la solidaridad.

\section{Problematizando la alteridad}

La alteridad es un concepto relacional. Implica un nosotros y está inextricablemente vinculado con la identidad. La alteridad se ha generado siempre desde un nosotros y ya en la modernidad desde un yo, un sujeto. El otro es aquel que mantiene una diferencia respecto al nosotros. Así, desde la perspectiva individual, el otro son todos. Desde el nosotros, el otro son otras conceptualizaciones grupales o identitarias. Por lo tanto, es necesaria la presencia de la identidad como condición para pensar la alteridad. La alteridad se podría plantear como una identidad en negativo.

Esta visión de la alteridad, más propia del sentido común que del análisis profundo del fenómeno establece un punto de partida. La consideración de la diferencia. En cambio, la solidaridad parte precisamente de la igualdad, del prójimo como parte de un mismo todo, con la identificación, con la empatía. ¿Cómo es posible hablar del otro de la solidaridad? Una vez más la paradoja entra en escena. Solidaridad y diferencia. Lógica de la igualdad e identificación con la lógica de la diferencia. El otro de la solidaridad como expresión de términos antitéticos. Si se intenta dar sentido a esta aparente contradicción, se dibujan diferentes caminos explicativos.

Cornelius Castoriadis defiende una triple posibilidad de posición del otro: superioridad, igualdad e inferioridad. Desecha las dos primeras como insostenibles y la tercera como probabilidad extrema, proclividad "natural" de las instituciones humanas. Des de la perspectiva del racismo, se descubre un cambio en la consideración de la alteridad. Se pasa de una posición de superioridad respecto al otro, en el sentido en que cada cultura defiende su imaginario como verdad absoluta, a un nuevo paradigma en que la consideración del otro como igual parece plausible. Donde el otro no supone una amenaza a la propia identidad. Castoriadis busca explicación al cambio:

\footnotetext{
5 Hoy en día, ya aparecen imágenes de niños y niñas del sudeste asiático. En un primer momento, solo aparecieron imágenes de destrucción. Con eso se podría decir, que la imagen del otro de la solidaridad son niños, al margen de su especificidad étnica.
} 
"¿Cómo podría aceptar una cultura que existan otras culturas con las que no puede compararse y para las cuales es alimento lo que para ella es basura?, se vuelve uno de los problemas políticos prácticos mayores de nuestra época, llevado al paroxismo por la aparente antinomia que desgarra nuestra propia cultura. Pretendemos al mismo tiempo que somos una cultura entre otras y que esta cultura es única en tanto que reconoce la otredad de las otras (lo que nunca antes se había hecho y lo que las otras culturas no hacen con ella), y en tanto que ha planteado significados imaginarios sociales y reglas que se derivan de ellos, que tienen valor universal; para tomar el ejemplo más fácil, el de los derechos del hombre." (Castoriadis, 1987: 10)

Universalizar el propio imaginario permite introducir al otro dentro de un discurso de la equivalencia. El otro exterior ya no tiene que ser exterminado. En cambio, la situación aun no está tan clara con los otros internos, la inmigración, donde la asimilación se muestra como la pretensión concreta del objetivo global, universalizar el propio imaginario. Estrategia novedosa de relación con la alteridad: incluirla bajo la universalización del propio imaginario sin necesidad de exterminarla físicamente. En este sentido, Gilles Lipovetsky defiende un proceso de redefinición de la diferencia, del otro, bajo el influjo de la igualdad:

"A escala histórica, el cambio ideológico es decisivo, el otro de religión o raza ha perdido su carácter sustancialmente desemejante; la dinámica de la igualdad democrática ha cumplido su obra, el otro, en adelante, tiene una «identidad cultural», ya no es un ser ontológicamente inferior." (Lipovetsky, 2000: 153)

Que el ansia solidaria responde a una creciente resignificación de la diferencia como algo apreciable o patrimonial; que el ansia solidaria busca borrar la diferencia; que la solidaridad empieza como un fenómeno caritativo hacia el otro diferente, pero que se reinterpreta como un acto de ayuda entre miembros de una misma comunidad global. Cualquiera de estos caminos podría ser válido siempre y cuando se acepte una determinada concepción de la alteridad donde la diferencia e identidad son el centro.

Al margen de la concepción de la alteridad como diferencia, encontramos la concepción de la alteridad como oposición, como incomparabilidad, como juego al margen de la correspondencia igualdad-diferencia. Cornelius Castoriadis explica la incomparabilidad con la existencia del otro equivalente, "los otros son simplemente otros". Pero resuelve que esta consideración del otro como igual ha llevado inexorablemente a la consideración del otro como inferior en el momento en que surgen conflictos entre comunidades diferentes (Castoriadis, 1987: 5). En palabras de Baudrillard, la concepción de Castoriadis del otro como incomparable u odiado deja de estar en relación de necesidad con la introducción de la seducción:

"Lo que define la alteridad no es que los dos términos no sean identificables, sino que no sean enfrentables entre sí. La alteridad pertenece al orden de las cosas incomparables. No es intercambiable según una equivalencia general, no es negociable, pero circula en las formas de la complicidad y de la relación dual, tanto en la seducción como en la guerra. Ni siquiera se opone a la identidad: juega con ella, de la misma manera que la ilusión no se opone a lo real sino que juega con ello, de la misma manera que el simulacro no se opone a la verdad sino que juega con la verdad -más allá, por tanto, de lo verdadero y de lo falso, más allá de la diferencia-, de la misma manera que lo femenino no se opone a lo masculino sino que juega con lo masculino, en algún lugar más allá de la diferencia sexual. Todo lo que se pretende 
singular e incomparable, y no entra en el juego de la diferencia, debe ser exterminado, bien físicamente, bien por integración en el juego diferencial, donde todas las singularidades se desvanecen en el campo universal. Es lo que ocurre con las culturas primitivas: sus mitos han pasado a ser comparables bajo el signo del análisis estructural. Sus signos han pasado a ser intercambiables a la sombra de una cultura universal, a cambio de su derecho a la diferencia. Negados por el racismo, o arrasados por el culturalismo diferencial, significaba en cualquier caso para ellos la solución final. Lo peor está en esta reconciliación de todas las formas antagónicas bajo el signo del consenso y de la buena convivencia. No hay que reconciliar nada. Hay que mantener abiertas la alteridad de las formas, la disparidad de los términos, hay que mantener vivas las formas de lo irreducible." (Baudrillard, 2000a: 166-167)

Baudrillard ofrece una nueva concepción de la alteridad, como alteridad radical. Al mismo tiempo propone un proceso de inclusión en el juego de la diferencia, de lo comparable. Esto supone un nuevo estatus de la alteridad, una forma tendencialmente desaparecida. Entre los recursos discursivos de Baudrillard, la melancolía o la referencia a lo que se pierde en la actualidad, el desencantamiento del mundo, se vuelve una constante. A pesar de los condicionantes de esta fórmula explicativa, se descubre un proceso que podríamos llamar de inclusión. La lógica de la inclusión se puede entender como un método de traducción, de asimilación al modelo hegemónico, al imaginario instituido. En este proceso hay identificación, comparabilidad, creación de sentido, situación funcional. El pensamiento racional positivista propio de la modernidad, conlleva este proceso de inteligibilidad global. La alteridad, a su vez, es tratada del mismo modo, la alteridad se hace inteligible, asumible. La alteridad empieza un tránsito hacia la desaparición.

Tanto Castoriadis como Baudrillard apuntan ese nuevo estatus de la alteridad. Donde el otro deja de ser directamente odiado. Donde se intenta mantener que los otros son simplemente otros, lo que Castoriadis defendía como una creación histórica que se abre paso a contracorriente de las tendencias "espontáneas" de la institución de la sociedad (Castoriadis, 1987: 4), las tendencias del racismo. Para Castoriadis una rareza histórica que solo se entiende bajo una pretendida universalización de valores cosmopolitas de Occidente. En Baudrillard, bajo su retórica provocativa, defiende una desaparición de la alteridad radical y una producción de la alteridad como diferencia.

\section{Producción del otro}

La alteridad se ha vuelto algo cotidiano, manejable, ya no está opuesto, sino yuxtapuesto o incluso como lo mismo. Incluso la diferencia cada vez se difumina más. La raza deja de ser aprehensible, incluso incorrecta. La alteridad desaparece porque nada parece tener el potencial para desafiar el imaginario instituido, nada puede quedarse fuera de la capacidad inclusiva del imaginario hegemónico. La alteridad radical desaparece, solo un hipotético contacto con vida extraterrestre podría suponer la oposición con formas radicalmente opuestas de experimentar el mundo. A pesar de ello, el hecho que concibamos la presencia de vida extraterrestre ya prepara el camino para la inclusión. Se traduce lo impensable hacia lo pensable. La alteridad radical en el sentido de Baudrillard ha desaparecido, se experimenta una carencia que se suple con la era de la diferencia. Cuando todo puede ser inteligible y comparable, el otro se debe producir como diferencia:

"Con la modernidad, entramos en la era de la producción del otro. Ya no se trata de matarlo, de devorarlo, de seducirlo, de rivalizar con él, de amarlo o de odiarlo; se trata fundamentalmente de producirlo. Ya no es un objeto de pasión, es un objeto de producción. 
¿Es posible que el Otro, en su singularidad irreducible, se haya vuelto peligroso o insoportable, y sea preciso exorcizar su seducción? ¿O más sencillamente la alteridad y la relación dual desaparecen progresivamente con el aumento de poder de los valores individuales? El caso es que la alteridad se echa en falta, y que es absolutamente necesario producir al Otro como diferencia, si no queremos vivir la alteridad como destino." (Baudrillard, 2000a: 156-157)

Se apunta a un cambio en el estatus simbólico de la alteridad. Con la producción, el otro ya no está intacto sino que se configura a partir de los deseos del productor, normaliza su diferencia a parámetros asumibles. Inclusión, desaparición y producción son tres pasos de un mismo proceso sobre la alteridad. La producción como diferencia, reduce la alteridad a una cuestión de identidad cultural. Se reconoce un único mundo o imaginario global bajo el que conviven alteridades de diferencial cultural. La convivencia, no deja de suponer una negociación, un diálogo. En el sentido que proponía Baudrillard, seria imposible concebir la convivencia con la alteridad. Pero quizás la noción de Baudrillard asume una caducidad extrema al otro, una incapacidad de resistencia intacta. Esto plantea un interrogante sobre las posibilidades de concepción del otro radical que plantea Baudrillard, ya que desparece al normalizarlo. La pregunta seria ¿queda algo intacto? ¿Queda algo fuera del sentido? ¿Queda algo bajo el signo de la ilusión? Esto no nos compete aquí, más allá de apuntar esta posible crítica a un esquema excesivamente cerrado, deudor de un estilo descaradamente provocativo. Al margen de esto, para el propósito de esta aproximación al imaginario de la solidaridad, nos interesa caracterizar el otro de la solidaridad y éste se entenderá producido como diferencia.

\section{Condiciones de producción}

Bajo el signo de la producción, el otro de la solidaridad aparece como un campo de relación peculiar. Antes se apuntaban dos procesos simultáneos: filantropismo y xenofobia. El primero aceptado hegemónicamente y el segundo denostado como inaceptable, bajo el dominio de lo correcto políticamente, aunque nadie ignora la ambivalencia existente. Incluso se podría argumentar sobre la inexistencia de oposición entre el filantropismo y la xenofobia. En el domino de lo obvio la sospecha siempre debe estar presente. La producción del otro de la solidaridad no responde a las características del otro en sí, sino que es asimilado a nuestros deseos e imágenes. Así, el racismo parece esconderse bajo el filantropismo exhibido. En el siguiente punto se proponen tres posibles paradas en el proceso de producción simbólica del otro: la desgracia, la indiferencia y la responsabilidad.

\section{Desgracia}

La producción de la alteridad va estrechamente ligada a su desgracia. El otro ya no supone un desafío a nuestra identidad por la incomparabilidad de la suya, sino por su desgracia. Incluso la diferencia del otro se ve eclipsada por esta cualidad fundamental del otro de la solidaridad, la desgracia. Qué fue primero, ¿la consideración desgraciada del otro como condición para el desarrollo de la solidaridad, o bien, un creciente ambiente solidario, de aproximación con el otro, que nos hace sufrir su desgracia? Correlaciones causales no dejaran más claro que la desgracia es una condición de producción del otro y que el centro de atención no está en las características del otro construido sino en las del propio productor: 
"En todas partes, el Nuevo Orden intelectual sigue las vías abiertas por el Nuevo Orden mundial. En todas partes, la desgracia, la miseria y el sufrimiento de los demás se han convertido en la materia prima y la escena primitiva. La victimalidad variada de los derechos del hombre como única ideología fúnebre." (Baudrillard, 2000b: 62)

El imaginario "Occidental" se alimenta de la desgracia del otro y a pesar de su culpabilización se legitima. La diferenciación del otro como desgraciado abre las puertas a la compasión, a la conmoción y, a su vez, a una especie de espíritu paternalista, continuamente negado por aquellos que lo ejercen. La producción del otro como desgraciado, produce un cierto efecto de legitimación del que se muestra solidario con su desgracia, ya que la desgracia remite a una especie de destino fatal, al margen de las condiciones anteriores. La conmiseración, aun situando el culpable en Occidente, solo hace que reproducir un modelo, incluir esa alteridad, volverla desgraciada. Se dibuja un círculo vicioso del que Baudrillard apunta una salida cuando dice que: "toda conmiseración está dentro de la lógica de la desgracia. Referirse a la desgracia, aunque sea para combatirla, es darle una base de reproducción objetiva indefinida. En cualquier caso, para combatir lo que sea hay que partir del mal, jamás de la desgracia." (Baudrillard, 2000b: 62) El mal supone una ruptura y no deja margen a la gradación de la desgracia. Si el otro se produce bajo el signo del mal, este crece como representación radical del otro, como algo opuesto. La cuestión es preguntarse sobre la existencia imaginaria del mal cada vez más socavado por la desgracia. Combatir la desgracia representa una perfecta inclusión del otro ya que exculpa todas las partes.

Pero, ¿de donde surge esta preocupación por el otro cuando más se habla del individualismo? Para esta cuestión se hace necesaria la introducción del otro-masa. La proximidad con el otro, la aprehensión de la desgracia se trata de representar de forma indolora. Lipovetsky argumenta a favor de esta visión, como es sabido, asumiendo el individualismo como punto de partida incontrovertible de su argumentación. Para Lipovetsky el "individualismo no es sinónimo de egoísmo: aunque se les haga cuesta arriba la retracción del yo. El individualismo no destruye la preocupación ética, genera en lo más profundo un altruismo indoloro de masas." (Lipovetsky, 2000: 133)

La cuestión seria preguntarse sobre la posibilidad de entender el individualismo como otra forma de comunidad difusa en las llamadas sociedades modernas. Al margen de eso, Lipovetsky nos aporta la cualidad indolora del altruismo de masas. Es decir, la inclusión de la desgracia del otro bajo nuestro imaginario instituido. Conmoción efímera, como un pequeño pinchazo que desaparece en pensar en otra cosa. Por lo tanto, tenemos una condición para que en sociedades "individualistas" se desarrolle una creciente preocupación por el otro: el efecto indoloro. El otro producido bajo la desgracia, pero de manera que su desgracia resulte indolora. Pero quizá, no se ha planteado la pregunta como se debería. Quizá es el individualismo una condición para producir la alteridad bajo el prisma de la desgracia. Quizá mejor dejar que Lipovetsky plantee la pregunta para luego buscar el porqué:

"Lejos de llevar únicamente al egoísmo o al cinismo, la nueva era individualista va a la par con lo que Nietzsche llamaba «la moral de la piedad universal». A fuerza de vivir sin grandes privaciones, el sufrimiento del otro -escenificado- se vuelve intolerable, funciona como una polución o una agresión a la calidad de vida. Si el neoindividualismo significa desculpabilización del egoísmo, está también acompañado de una mayor participación imaginaria y concreta de las desdichas del prójimo, pero sin que esa conmiseración desemboque, sin embargo en actos ejemplares. Como ya escribió Tocqueville en 1840, «en los siglos democráticos, los hombres se dedican raramente unos a otros, pero muestran una compasión general hacia todos los miembros de la especie humana»: las nuevas condiciones 
de vida consumista y psicologista no hacen más que acentuar esta tendencia a la identificación epidérmica con el otro, a la repugnancia ante el espectáculo del sufrimiento." (Lipovetsky, 2000: 140)

Estas líneas dejan al descubierto que la piedad universal o el filantropismo se abre espacio en el imaginario al mismo tiempo que la incipiente noción de individualismo. Por esta razón parece lógico plantearse la posibilidad de que el proceso de producción de la alteridad bajo el signo de la desgracia se inscriba en el mismo período. Estas consideraciones dibujan un largo período de fijación de lo que se ha llamado el imaginario de la solidaridad contra la sensación de novedad que el fenómeno pueda representar.

\section{Indiferencia}

En considerar el individualismo resulta recurrente tratar las palabras de Alexis de Tocqueville. Fascinado por el igualitarismo declarado de la sociedad estadounidense del siglo XIX, descubre un tipo de relación que llamó individualismo. Desde la perspectiva de Richard Sennett la noción del individualismo de Tocqueville se aproxima a la noción de indiferencia.

"Cuando, en el segundo volumen de La democracia en América, Tocqueville acuñó la expresión «individualismo», puso con toda claridad de relieve este problema. El individualismo, decía Tocqueville, consiste en el amor a la familia y a los amigos, pero en la indiferencia a todas las relaciones sociales que trasciendan esa esfera íntima. La igualdad sólo empeora el problema del individualismo; en efecto, puesto que la mayoría de la gente parece tener los mismos gustos, creencias y necesidades que nosotros, da la impresión de que se puede y se debe dejar a los demás que se arreglen con sus propios problemas." (Sennet, 2003: 203)

Curiosamente la interpretación de Sennett concurre en contradicción con la cita anterior sobre Tocqueville que apuntaba a la compasión acerca de la especie humana. La visión de Sennett destaca un tipo de comunidad familiar con indiferencia hacia el resto. Este es el tipo de interpretación sobre el individualismo común en nuestro imaginario, pero no parece corresponder con las dinámicas palpables. No explica el fenómeno de la solidaridad, ni de la relación con la alteridad. Si se asume la indiferencia como fenómeno cómo se explica la preocupación ética. Lipovetsky centra así esta cuestión:

“... si la cultura de la autoabsorción individualista y del self-interest es dominante hasta tal punto, ¿cómo explicar la aspiración colectiva a la moral? ¿Cómo seres vueltos sólo hacia ellos mismos, indiferentes al prójimo tanto como al bien público, pueden todavía indignarse, dar prueba de generosidad, reconocerse en la reivindicación ética? ¿Quid de la cultura individualista que glorifica el Ego pero que paradójicamente logra convertir en estrella las virtudes de la rectitud, de la solidaridad, de la responsabilidad? "(Lipovetsky, 2000: 10)

Valores de comunidad en sociedades individualistas. Quizás el individualismo solo sea un recurso interpretativo para un nuevo tipo de comunidad. Hoy en día, lo social entendido desde la perspectiva de la ideología de la modernidad deja paso a la identificación con múltiples comunidades y de forma 
simultánea ${ }^{6}$. Pero, ¿es la indiferencia uno de los pilares bajo el que se produce al otro de la solidaridad? La respuesta parece negativa. Cada vez nos preocupamos más por el otro, pero la efimeridad de esta preocupación deja al descubierto los límites, el alcance del otro de la solidaridad. A todo esto, se puede decir que el tratamiento del otro de la solidaridad resulta una buena plataforma para problematizar las concepciones individualistas.

\section{Responsabilidad}

¿Por qué el otro es producido como desgracia y se contradice con la noción de indiferencia, extendida en nuestro imaginario como actitud general, y problematiza la noción de individualismo? ¿Cual es el elemento que falta en la producción contemporánea de la alteridad para entender el otro de la solidaridad? Una vez más, el foco de atención no está en el otro sino en el nosotros. Aquí entra lo que se ha convenido llamar responsabilidad. La producción del otro se hace desde la responsabilidad del productor. Aquel que produce, produce al otro como responsable de su desgracia y en contradicción con una cualidad definitoria de nuestra sociedad en cuestiones imaginarias: la indiferencia. No somos indiferentes a la desgracia ajena y menos a la del otro, debido a que el otro es producido como desgraciado del que debemos hacernos responsables. Lipovetsky defenderá en última instancia que la responsabilidad solo responde a la autorrealización individual bajo un discurso de donación al otro:

"Con seguridad, la mayoría de personas dedica tiempo a actividades voluntarias declarando actuar en nombre de los grandes ideales humanistas: el amor al prójimo, hacer la vida más humana y solidaria. Pero más allá de estos referentes, es sobretodo el placer de encontrar al otro, el de deseo de valorización social, la ocupación del tiempo libre lo que constituyen las motivaciones esenciales del voluntariado." (Lipovetsky, 2000: 144)

Solidaridad como interés en el otro, o bien autorrealización personal mediante un otro producido desde nuestros deseos, un otro desgraciado al que ayudar y del que sentirse responsable. El primer término de la disyuntiva solo parece posible cuando el otro está intacto, con el otro radical, en términos de Baudrillard, aquel que es capaz de seducirnos. Si se conviene que el otro es producido como diferencia y ya no nos seduce, en ese caso, se habla de un solipsismo solidario. El segundo término de la disyuntiva coge fuerza. Solidaridad sin otro radical, solidaridad con un otro producido como desgracia, como producto aséptico e indoloro que reafirma una posición hegemónica en el imaginario instituido. A pesar de esta consideración, se asume una posición crítica con la utilización del individualismo como elemento explicativo y adecuado para el momento presente, quizás frena más que ayuda.

¿Qué conlleva la responsabilidad como pilar productivo de la alteridad? Y sobretodo, ¿qué condiciones imaginarias sustentan la consideración de la responsabilidad como elemento central? Para intentar dar respuesta a estos interrogantes se hará referencia a un proceso de implicaciones importantísimas en el "imaginario occidental" y que no ha recibido la consideración pertinente: la transición global de los deberes y donaciones a la noción de derecho. La noción del derecho, se afianza con la construcción del Estado, pero nos tenemos que remontar hasta el derecho civil romano. En esa época se hizo del derecho el centro vertebrador de la convivencia en sociedad. Con

6 Para más desarrollo de esta cuestión véase El Tiempo de las Tribus de Michel Mafesoli. 
la edad media, la noción de derecho se sepulta bajo la religión y el feudalismo. Pero la modernidad la recuperó. Un primer paso lo encontramos en la individualización que supone la doctrina protestante:

"el protestantismo puso el acento en el carácter espontáneo y voluntario de la ayuda a los demás. Lutero escribió que la caridad no puede ordenarse; para Calvino, la compasión era un «don gratuito del yo»." (Sennet, 2003: 199)

La individualización conlleva que la noción de responsabilidad con el otro se circunscriba a la dimensión individual. Se podría argumentar que la individualización permite eludir la responsabilidad en considerar que serán otros los que se harán cargo de ayudar al prójimo. Pero al contrario, y como se ha defendido antes, la individualización se traduce en la autorrealización personal, en un don gratuito del yo. Centralización del individuo como condición para el auge del derecho. El individuo se hace receptor de derechos, y el Estado garante de estos derechos. El individuo se siente legitimado para reclamar: "está en su derecho". En este proceso, se pasa a reconocer derechos y no obligaciones. Lipovetsky, en El crepúsculo del deber apunta el proceso de esta transición característica de la modernidad en relación a la moral:

"Ya sea en la esfera política, moral o económica, los derechos soberanos del individuo se han colocado en todas partes en primer plano: derechos del hombre, derecho de los placeres, derecho a la libre consecución de los intereses privados; este proceso es el que pudo autorizar a Leo Strauss a analizar la modernidad como una cultura en la que «el hecho moral fundamental y absoluto es un derecho y no un deber»." (Lipovetsky, 2000: 24)

¿Pero cómo se traduce esta expansión del derecho en la responsabilidad con el otro? La hipótesis que se propone es que en la producción del otro como desgracia, hay un reconocimiento de los derechos de la alteridad. Al no ser indiferentes a la desgracia del otro y éste producido como diferencia, el otro se identifica esencialmente como otra parte de lo mismo, el otro producido lo es para identificarse con él. En el sentido en que el otro es producido como diferencia pero también como parte de lo mismo, hay un reconocimiento de sus derechos. El otro individualizado tiene derechos ya que, parafraseando escritos sagrados, el otro es producido a imagen y semejanza de nuestros deseos.

El otro de la solidaridad no deja de ser una producción concreta de un imaginario que concibe los individuos como poseedores de derechos. Esto presenta una puerta interesante para jugar pensado: ¿los Derechos Humanos como derechos de la alteridad? Quizás en otros trabajos. Por ahora, la atención se centra en el otro de la solidaridad, de quien se precisa responsabilizarse para garantizar sus derechos. El otro producido como desgracia de la que no se es indiferente, al que se le reconocen derechos y del que debemos responsabilizarnos.

Lejos de dar respuestas se han planteado interrogantes que inciten la reflexión. Se ha pretendido aportar un juego terminológico que ayude a dilucidar aspectos identificables en la producción del otro de la solidaridad. Deliberadamente, se ha obviado el papel fundamental que los principales medios de producción de la alteridad ejercen, a tratar seguidamente. Bajo la lógica del consumo, espectáculo y emoción, la conmoción efímera permite convivir con un otro desgraciado del que debemos hacernos responsables. 


\section{Sociedad de Consumo}

La Sociedad Contemporánea está caracterizada por ser el consumo una práctica central. Más allá de poder ser considerado un comportamiento individual, es un fenómeno social que posibilita la creación de identidades en un contexto donde nos definimos por lo que consumimos. Estos consumibles que nos permiten decirnos y decir a los otros "quienes somos" se revisten de significados y símbolos socialmente construidos y son estos símbolos los que utilizamos para comunicarnos. Así, el consumo no es simplemente una práctica necesaria en la cadena económica, sino un modelo que explica la forma que tenemos de relacionarnos.

Se sostiene sobre una capa de emotividad que lo convierte en la experiencia más verdadera, en la expresión de una emoción. Y la emoción es entendida como lo auténtico, lo verdadero, lo natural, la expresión máxima de individualidad (en el sentido de lo que nos hace diferentes a los demás). Pero las emociones son discursos sociales. La conexión entre el individuo y la sociedad se evidencia en el consumo de emociones.

Las emociones pertenecen al ámbito de lo simbólico, adquieren significado en la interacción social; es aquí donde se define qué es emoción y qué no, y más aún, donde se delimita qué emoción se puede expresar y cuál controlar. Su propia explicación, narración y definición para con nosotros mismos y los otros es el propio proyecto de subjetividad social en construcción.

Un ejemplo de la función comunicativa del consumo es el uso de imágenes para expresar emociones y el consumo de estas imágenes, siempre acomodadas en el imaginario social dominante.

Lo interesante en este entramado de prácticas y discursos es el papel que cumplen las emociones en la sociedad moderna occidental. Además de ser el consumo de emociones un componente de la construcción de nuestra identidad (cambiante, múltiple y social), las emociones funcionan como dispositivo de control social.

Según la concepción de Foucault, este "es una red que se establece entre los elementos heterogéneos pertenecientes tanto a lo dicho como a lo no dicho". Este es el sentido en que se entienden las emociones en tanto prácticas discursivas que mantienen y reproducen las relaciones de poder que conforman la sociedad. El consumo de emociones y las emociones como consumo dan cuenta del proceso de creación y mantenimiento de nuestra sociedad actual.

\section{Consumo de Solidaridad}

Muy relacionado con las emociones, y con su función de dispositivo de control social en una sociedad donde todo es consumible, tiene sentido la solidaridad como un bien a consumir en el mercado de las emociones. Las ONG's como agencias de servicio, ofrecen la posibilidad de participar en la compraventa de las "buenas intenciones". Las prácticas solidarias que se ofrecen, como en todos los sectores del mercado, están adaptadas a las posibilidades y/o preferencias de cada cual. Desde la donación de una pequeña cantidad de dinero, a la participación en voluntariado o en un proyecto de cooperación, todas están basadas en un discurso del desarrollo que marca la dicotomía nosotros/ellos.

Lipovetsky explica el fenómeno del consumo de solidaridad por un cambio en el ámbito de la moral. Según el autor, una moral basada en la obligación y el deber, la dedicación y el sacrificio por el 
prójimo, ha dejado paso a un movimiento posmoralista, donde el individuo contemporáneo expresa sin vergüenza la prioridad individualista de sus elecciones. Prima el placer y la dedicación a uno mismo.

No es una muerte de los valores, como algunos autores defienden, ni se puede traducir por indiferencia. Es un paso hacia una moral que no constriñe, no obliga, y legitima los derechos subjetivos. Así, el individualismo de la modernidad se opone a la entrega, a la renuncia. Pero se preocupa por la beneficencia, quiere ayudar a los otros sin comprometerse demasiado, que sea fácil, que la solidaridad no duela. El llamamiento a la solidaridad debe conmover, tocar los sentimientos, pero su práctica no puede implicar sufrimiento y sobre todo, no puede ser obligado.

El imperativo a consumir compromiso tiene como condición que el compromiso sea adquirido en libertad y el objetivo es concreto, una causa específica. El consumo de solidaridad no puede pesar demasiado; se concretiza en prácticas puntuales, y en muchos casos ejercidas desde la distancia.

Las grandes causas producen incredulidad porque las odiseas ideológico-políticas no funcionaron.

Otros autores relacionan esto con el gusto por lo inmediato y con la actual percepción del tiempo. La causa a la que nos comprometemos, o mejor dicho, la práctica que adquiere dicho compromiso, no puede ocupar demasiado del tiempo que tenemos disponible. En este sentido los llamamientos a la solidaridad nos facilitan la entrega de donativos con sólo pinchar en la página web o con una llamada telefónica.

A la moral reinante Lipovetsky la califica como sentimental-mediática. El adjetivo sentimental se refiere al papel que las emociones desempeñan. El apelativo a la solidaridad tiene que conmover; el espectáculo del sufrimiento del otro exalta el sentimiento, emociona. Una vez más, las emociones cumplen su función; su expresión y su control son necesarios para el mantenimiento de la subjetividad contemporánea.

La beneficencia mediática funciona como una nueva modalidad de consumo de masas; la caridad se convierte en un gran espectáculo y se une el placer con la buena intención. Un ejemplo de esto son los telemaratones, donde son combinados la "causa" y el entretenimiento en forma de conciertos, cómicos, etc. El poder del espectáculo hace que se dé una gran afluencia caritativa, especialmente en causas sentidas como urgentes, mientras el contador en la pantalla nos informa del record en solidaridad que hemos alcanzado.

Así, se cumplen las nuevas aspiraciones consumistas, más emocionantes y participativas, pero encuadradas en una conciencia ética ligera, puntual, temporal e indolora. Los media desencadenan grandes gestos de solidaridad, pero correlativamente liberan de compromiso a los individuos.

\section{El discurso de lo obvio}

"La pregunta que debemos hacernos ante el Forum 2004 es la siguiente: ¿Cómo criticar un discurso -político, cultural, económico- que se presenta con el lenguaje del no-poder para ejercer mejor el poder? Esta es la cuestión y la extrema dificultad a la que nos enfrentamos." (Espai en blanc, 2004: 7) 
Así iniciaban los compañeros de Espai en Blanc su crítica a lo que significo el Forum de las Culturas que se celebro en Barcelona en el año 2004. Cómo enfrentarse a ese acontecimiento que quería simbolizar todo lo políticamente correcto y que se revestía con todos los conceptos que ya se han salido de la orbita de la discusión intelectual crítica. Cómo oponerse al discurso de la paz, la solidaridad, el consenso, la democracia, que intenta tender un puente hacia los que no tienen voz. Cómo rechazar el discurso de lo obvio.

En nuestro intento de problematizar el discurso de la solidaridad nos encontramos en una disyuntiva nada nueva, poner en duda lo indudable, atacar lo más sagrado, plantarle cara al fascismo postmoderno. La solidaridad se erige como uno de los pilares donde se aguanta este discurso de lo obvio, un concepto que ya ha sobrepasado su estado problemático para acomodarse definitivamente en el lado bueno de nuestro imaginario social, en el imaginario instituido en palabras de Castoriadis. Nadie en su sano juicio se atrevería a poner en entre dicho el discurso solidario. Sería aceptada la crítica a las prácticas de esta solidaridad, en el supuesto de que se realizaran con mala fe o en contra de los intereses de a quien se la aplica. Pero la crítica que se propone aquí sobrepasa las aplicaciones funcionales o, como diría R. K. Merton, disfuncionales de la solidaridad para atacar la raíz misma de su envoltorio. La solidaridad esconde ante los ojos de todos nosotros su verdadera cara, su espoleta carga por el sistema capitalista, dispuesta a ser detonada en el momento oportuno. La solidaridad es uno de los pilares del discurso de lo obvio, de esa realidad obvia, intocable, fascista.

"El Forum 2004 es el laboratorio del fascismo postmoderno porque produce, como hemos dicho, una realidad obvia. Una realidad obvia, mediante principios que solo un necio podría cuestionar. Conocemos bien los tres que conforman el Forum 2004: paz, diversidad y sostenibilidad. ¿Alguien podría oponerse a uno solo de ellos? Claro que no. Son las obviedades de lo políticamente correcto. Ante ellos no podemos más que asentir y cerrar la boca. Si además el Forum 2004 se presenta como una defensa del diálogo, como una llamada a participar incluso críticamente, entonces está claro que no hay lugar desde donde denunciarlo." (Espai en blanc, 2004: 7)

Los tres pilares del Forum de las Culturas, paz, diversidad y sostenibilidad se ven atravesados por el discurso de la solidaridad. Las culturas deben ser comprendidas en su diversidad, respetadas y ayudadas a respetar su entorno biológico. Para ello el discurso solidario despliega con toda su vehemencia su poder persuasivo: tú puedes ser participe de ese movimiento de desarrollo limpio en lo económico, cultural y social del Tercer mundo. Por que, al fin y al cabo, de eso estamos hablando, del Otro, del extranjero pobre. Pero no el que nos cruzamos en el metro o en la esquina sino el que está allá, en esa frontera mítico-mágica del afuera. Pero ese afuera ya no lo es tanto, el mundo se ha unido en un destino común, el capitalismo liberal.

El movimiento es uno de los pilares del fascismo postmoderno, esa movilización total de la vida es necesaria para sustentar lo obvio en una ideología concreta. Esa correspondencia entre lo realhistoria-obvio se impone a cualquier punto de crítica. El segundo fundamento de esta nueva forma de opresión es el multiculturalismo. La diversidad debe ser administrada para crear un panorama multicultural donde el discurso de la solidaridad circula a la velocidad de la luz. Las diferencias ya no son peligrosas por que actúan a partir del mismo patrón de movimiento y puesta en circulación. Por último, la despolitización de la vida cierra la realidad obvia en la que morimos cada día. El fin de lo político se cierne sobre nosotros en forma desconflictivización de la vida social. La política es la que debe ocupar el puesto del antagonismo, en el mundo real la actuación ciudadana no es bienvenida. El 
conflicto está expurgado en una sociedad de suma cero, donde la muerte y el mal han sido eliminados como posibilidad, a no ser que sea para exorcizarlo.

El discurso de lo obvio se cierra sobre si mismo, sobre su propia tautología omnipresente. Las vidas son movilizadas, no en pro de un futuro mejor sino de un proyecto vital sin fin. La ciudad se mueve, el mundo se mueve, nosotros lo movemos con nuestra vida. La vida se erige entonces como un valor propio del cual debemos cuidarnos para el buen funcionamiento de todo lo humano. La solidaridad se muestra aquí con los incipientes movimientos sociales que no sólo trabajan al Otro, sino a lo Mismo.

El proyecto, la multiculturalidad y la neutralización de lo político se convierten en los ejes de esa lógica que conforma la realidad obvia. Además, todo este mecanismo de represión se desarrolla en la llamada sociedad red, aunque sería más adecuado decir que la red es su verdad.

"La red es un mecanismo selectivo, jerárquico y de control. Su verdad, la que día a día soportamos, se resume así: o te conectas o te mueres (socialmente). Esa coacción, esa obligación a movilizarse y a participar bajo amenaza de muerte, ese vivir sin otra salida que la permanente conexión, eso es el fascismo postmoderno: la participación que se confunde con la propia vida porque no deja otra salida." (Espai en blanc, 2004: 5)

En este contexto es donde la crítica a la solidaridad se vuelve una misión complicada, una misión incluso molesta. Cómo explicar que no estas a favor de que los niños en el África occidental no dispongan de agua potable. Cómo oponerse a que se le de a los sin tierra medios para sobrevivir. A estas cuestiones sólo podemos contestar que no hablamos de lo mismo, que nuestro interés no se centra en esas cosas. Simplemente intentamos desentrañar qué hay detrás de esa realidad obvia que oprime con todo el peso de lo real.

"Con esta evacuación del conflicto se bloquea toda referencia al antagonismo, a la resistencia provocada por la nueva forma de poder. La posibilidad de un enfrentamiento político con el sistema queda sencillamente anulada del imaginario social, relegada a un lugar de sombras violento, terrorífico, amenazante-, al que sólo se invoca para exorcizarlo." (Espai en blanc, 2004:24)

Nos queda la rabia, nos queda el odio a la vida que no quiere ser vivida. Esa es nuestra única arma contra el dominio de lo obvio. El discurso de la solidaridad recorre todo el imaginario social y pisa con fuerza la diferencia, no para exterminarla sino para hacerla desaparecer bajo su forma.

\section{Referencias}

Baudrillard, Jean (2000a). El crimen perfecto, Barcelona: Anagrama.

Baudrillard, Jean (2000b). "Ninguna piedad para Sarajevo" en Pantalla Total, Barcelona: Anagrama.

Bauman Zygmunt (1993). Modernity and Ambivalence. Londres: Polity Press

Castoriadis, Cornelius. (1989). La institución imaginaria de la sociedad, vol. 2: El imaginario social y la institución. Barcelona: Tusquets.

Castoriadis Cornelius (1996). Entrevista con Fernando Urribarri, Zona Erógena, num.31, Buenos Aires. 
Castoriadis, Cornelius (1987). Reflexiones en torno al racismo. ESTUDIOS. filosofía-historia-letras, http://www.hemerodigital.unam.mx/ANUIES.

Carrizo, Luís. (1998). Cornelius Castoriadis, el filósofo de la imaginación social. Revista de Educación y Derechos Humanos (SERPAJ), Cuadernos para docentes, número de noviembre de 1998.

Diccionario de Uso de la Real Academia Española, 1739.

Diccionario de la RAE, 1984.

Espai en blanc (2004). Informe Barcelona 2004: El fascismo postmoderno. Barcelona. http://www.espaienblanc.net

Hegel, F.G.W. (1976). Filosofía de la historia. Buenos Aires: Claridad.

Jaeger, Werner (1947). La teología de los primeros filósofos griegos. Fondo de Cultura Económica: Ciudad de México, 1998.

Lipovetsky, Gilles (2000). El crepúsculo del deber, Barcelona: Anagrama.

Lyotard, Jean François (1996). La tierra no tiene senderos por sí misma. Moralidades posmodernas. Tecnos: Madrid.

Ibáñez Tomás (2003). Contra la dominación. Barcelona: Gedisa.

Sanguinetti, Javier (1999). Provocando lo sagrado (1), La dimensión trágica del ser. Buenos Aires: Mediarte.

Sennett, Richard (2003). El Respeto; Barcelona: Anagrama.

Williams, James (1998). Lyotard: Towards a Postmodern Philosophy. Cambridge \& Malden, MA: Polity Press.

\section{Formato de citación}

Baltà, Joan; López, Cristian; Medina, Laila; Passols, Pablo; Vargas, Liliana (2006). Imaginando la solidaridad. Athenea Digital, 9. Disponible en http://antalya.uab.es/athenea/num9/balta.pdf.

Joan Baltà. Licenciado en Sociología por la Universidad de Barcelona (España). Actualmente realizando el Doctorado de Psicología Social de la Universidad Autónoma de Barcelona.

Cristian López. Licenciado en Sociología por la Universidad de Barcelona (España). Actualmente realizando el Doctorado de Psicología Social de la Universidad Autónoma de Barcelona.

Laila Medina. Licenciada en Psicología por la Universidad de Granada (España). Actualmente realizando el Doctorado de Psicología Social de la Universidad Autónoma de Barcelona.

Pablo Passols. Egresado de la carrera de Ciencias de la Comunicación (Universidad de Buenos Aires, Argentina) y Máster en Intervención Ambiental (Universitdad de Barcelona). Actualmente realizando el Doctorado de Psicología Social de la Universidad Autónoma de Barcelona. 
Liliana Vargas. Actualmente realizando el Doctorado de Psicología Social de la Universidad Autónoma de Barcelona.

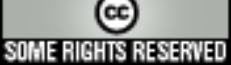

Este texto está protegido por una licencia Creative Commons.

Usted es libre de copiar, distribuir y comunicar públicamente la obra bajo las siguientes condiciones:

Reconocimiento: Debe reconocer y citar al autor original.

No comercial. No puede utilizar esta obra para fines comerciales.

Sin obras derivadas. No se puede alterar, transformar, o generar una obra derivada a partir de esta obra.

\section{Resumen de licencia}

$\underline{\text { Texto completo de la licencia }}$ 